\title{
EDITORIAL
}

\section{CONTENTS OF OTHER JOURNALS FROM THE REGION}

\section{SZOCIOLÓGIAI SZEMLE}

http://www.szociologia.hu/2016_2_szam/Issue No. 2. 2016

Berger Viktor: Georg Simmel térelmélete(i); Éber Márk Áron: Kritika és korrekció: Mennyiben sikeres Pokol Béla Luhmann-kritikája és társadalomelméleti szintéziskísérlete?; Polese, Abel - Kovács Borbála - Jancsics Dávid: Az „állam ellenére” és az „államon túl” megvalósuló informális gyakorlatok ártalmas és ártalmatlan természete: magyarországi és romániai példák; Syi: A büntetéshez való viszonyról; Kovai Cecília: A cigány-magyar különbségtétel hatása a cigány közegek szerveződésére

\section{SOCIO.HU}

http://socio.hu/ Issue No. 3. 2016

Kmetty Zoltán - Koltai Júlia Anna: Státuszelérés, társas támogatás, társadalmi törésvonalak. A kapcsolathálózati integráció aspektusai; Albert Fruzsina Dávid Beáta: A magyarországi kapcsolathálózati struktúrák jellemzői 2015-ben; Csurgó Bernadett - Megyesi Boldizsár: Képzelt különbségek. A városi és vidéki közösségek, társas kapcsolatok kvantitatív vizsgálata; sillag Sára - Gáspár Tamás - Géring Zsuzsanna - Király Gábor - Kováts Gergely - Köves Alexandra - Sebestyén Gabriella: Rendszermodellezés a felsőoktatásról. Jelentésadás egy részvételi folyamatban; Bódi Balázs - Takács-Sánta András: Tikopia társadalma, amely elkerülte a közlegelők tragédiáját 


\section{SOCIETY AND ECONOMY}

http://www.akademiai.com/toc/204/current Issue No. 3. 2016

Bohdan Vahalík-Michaela Staníčková: Key factors of foreign trade competitiveness: Comparison of the EU and BRICS by factor and cluster analysis; Ladislava Issever Grochová-Kateřina Myšková: How efficiently are the EU countries coping with the discrepancy between economic and environmental goals; Petr David:The effects of increased VAT rates applied in the EU member states in 2014; Svatopluk Kapounek-Vlasta Kašparovská: Dynamic provisioning as an automatic stabilizer of the financial instability; Vlasta Kašparovská-Jana Laštůvková-Luboš Střelec: Is the exchange rate a factor of bank liquidity changes? Study of the Czech Republic; Lea Kubíčková-Martina Toulová-Marcela TuzováLucie Veselá: The internationalization motives of SMEs from the Czech Republic in the context of EU accession; Jan Čadil-Karel Mirošník-Ludmila Petkovová: Impact of R\&D subsidies on enterprise performance in the Czech Republic; Kamila NovákováRaúl Compés LópezJosé María García Álvarez-Coque: Ethical certification in the Spanish agrifood industry: An alternative paradigm?

\section{INTERSECTIONS. EAST-EUROPEAN JOURNAL OF SOCIETY AND POLITICS}

http://intersections.tk.mta.hu/index.php/intersections/issue/view/6/showToc Issue No.2. 2016

Attila Melegh, Iván Szelényi, Polanyi Revisited. Introduction; Kari Polanyi Levitt, Letter to Intersections.EEJSP; György Lengyel, Embeddedness, Redistribution and Double Dependence: Polányi-reception Reconsidered; Chris Hann, Cucumbers and Courgettes: Rural Workfare and the New Double Movement in Hungary; József Böröcz, Global Inequality in Redistribution: For A World-Historical Sociology of (Not) Caring; Gabor Scheiring, Sustaining Democracy in an Era of Free Markets: Karl Polanyi's Perspectives on the Politics of Finance; Adrian Brisku, Empires of Conquest and Civilization in Georgian Political and Intellectual Discourse since Late Nineteenth Century 


\section{POLISH SOCIOLOGICAL REVIEW}

http://polish-sociological-review.eu/ Issue No. 3. 2016

Andrzej K. Koźmiński-Adam Noga-Katarzyna Piotrowska-Krzysztof Zagórski: The Balanced Development Index: Its Construction and Application in Times of Uncertainty, Poland 1999-2017; Anna Domaradzka-Filip Wijkström: Game of the City Re-negotiated: the Polish Urban Re-generation Movement as an Emerging Actor in a Strategic Action Field; Dominika Latusek-Tomasz Olejniczak: Development of Trust in Low-Trust Societies; Seweryn Rudnicki: Complexity, Institutions, and an 'Agile’ Disability Policy; Tomasz Masłyk-Ewa Migaczewska: Analysis of the Dynamics of the Internet Use by Persons with Disabilities in Poland over the Decade 2003-2013 in the Context of Their SocioDemographic Characteristics; Karmen Erjavec-Suzana Žilič Fišer: Aging Adults about Online Dating: "I am back on the relationship market!"; Józef M. Fiszer: From Political Transformation to Europeanization and Democracy in the New European Union Member States: An Attempt to Review Results; Attila Ágh: The Singularity of Poland or the Common Historical Trajectory in ECE?

\section{SOCIOLOGICKÝ ČASOPIS / CZECH SOCIOLOGICAL REVIEW}

http://sreview.soc.cas.cz/en/issue/current Issue No. 5. 2016

Vlastimil Havlík, Michal Kubát, Changes in Czech Parliamentarianism and Partisan Politics after 1989; Miloš Brunclík, Michal Kubát, The Czech Democratic Regime after 2012, A Transition to Semi-Presidentialism?; Lukáš Linek, Roman Chytilek, Otto Eibl, Defence, Acquisition or Non-Competition? How Did the Form and Intensity of Czech Party Competition Change between 2006 and 2014? ; Vít Šimral, Changes in the Czech Party System through the Lens of Political-Party Accounting; Petra Svačinová, Empty Promises? Election Promise Fulfilment among Coalition Parties in the Czech Republic between 2006 and 2015; Petr Mareš, Ivo Možný (31. 8. 1932 - 10. 9. 2016); Jaroslav Stř́itecký, Zemřel Ivo Možný; Miloš Havelka, Sociologie jako program, K neakademickému myšlení Ivo Možného; Martin Potůček, Vzpomínky na Iva; Marek Skovajsa, $K$ 70. narozeninám Ilji Šrubaře; Zdeněk R. Nešpor, Sto let od narození zakladatele české demoskopie Čeňka Adamce (19. 11. 1916 - 12. 10. 1997); Josef Bečvář, Ke stému výročí narození Čeňka Adamce, spoluzakladatele české demoskopie 


\section{SOCIOLÓGIA - SLOVAK SOCIOLOGICAL REVIEW}

http://sociologia.sav.sk/en/static.php?id=1153 Issue No. 5. 2016

Vašečka, M. Za profesorom Ivom Možným; Charvát, J. National or Bratislava Council? National District, Proportionality, and Territorial Representation in Slovak Parliamentary Elections; Repková, K. Utilization of the Social Role Valorisation Concept in the Sector of Social Services; Šprocha, B. - Šídlo, L. Nováková, G. - Št’astná, A., Cohort Changes in the Concentration of Fertility in the Czech Republic and Slovakia; Tížik, M., The Beginnings of an Institutionalized Sociology of Religion and the First Survey of Religiosity in Slovakia

\section{REVIJA ZA SOCIOLOGIJU}

http://hrcak.srce.hr/index.php?show=toc\&id_broj=13048 Issue No.1. 2016

Petra Sinovčić, Boris Milavić, Vesna Trut, Relationships between Postmaterialistic Values and Religiousness, Attitudes towards Nationalism, and Attitudes towards Gender Roles among High School Students in the City of Split; Sanja Stanić, Fundamental Attributes of the Theory of Consumption in the Work of Jean Baudrillard, Pierre Bourdieu, and George Ritzer; Karin Doolan, How Has a Discussion of Županov's Work Highlighted Divisions in (Croatian) Sociology?; Božo Kovačević, Društvena teorija i postnormalna znanost ; Božidar Jakšić, In memoriam Nebojša Popov (1939-2016); Dragan Bagić; In memoriam Milan Mesić (1948-2016)

\section{SOCIOLOGIJA. ČASOPIS ZA SOCIOLOGIJU, SOCIJALNU PSIHOLOGIJU I SOCIJALNU ANTROPOLOGIJU}

http://www.komunikacija.org.rs/komunikacija/casopisi/sociologija Issue No.3. 2016

Rada Drezgić, Istorija kontrole rađanja u Srbiji: sprečavanje i/ili prekid trudnoće; Zorana Antonijević, Državni feminizam u Srbiji - institucionalizacija feminističkih politika i praksi?; Vera Backović, Dominantni pristupi u proučavanju procesa džentrifikacije; Dražen Pavlica, Vjerskofundamentalistički svjetonazor; Zorana Medarić, Maja Zadel, Martina Rameša, Međuetničko nasilje i principi međukulturnog obrazovanja u školama: studija slučaja Slovenije; Olivera Pavićević: Koncept otpornosti u sociologiji; Marina Savković, Mladi na tržištu rada u savremenim uslovima: jedno poređenje Evropske unije i Srbije; Vera Vratuša, Privatizacija i klasni Jelena Petković: interesi; Tanja Svilanović: Slađana 
Dragišić Labaš, „Aktivno starenje u Beogradu“;Nikola Božilović, „Ogledi o popularnom“"

\section{TEORIJA IN PRAKSA}

http://www.fdv.uni-lj.si/en/journals/science-journals/teorija-in-praksa Issue No.5 2016

Romana Korez Vide, Milan Jurše: The role of stereotyping in a culturally diverse international business environment; Rok Zupančič, Jana Arbeiter: 'Primitive, cruel and blood-thirsty savages': stereotypes in and about the Western Balkans; Boštjan Udovič, Maja Bučar: "Mirror, mirror, on the wall...": Slovenian development assistance in the Western Balkan countries and its reputation in the region; Matevž Rašković And Davor Vuchkovski: National stereotypes and social distance towards slovenians among former Yugoslav countries: 25 years later; Andreja Jaklič, Marjan Svetličič: Do stereotypes hinder or promote foreign direct investment? The case of Western Balkan countries; Marko Lovec, Ana Bojinović Fenko: National stereotypes as a co-determinant of bilateral relations: the case of the Western Balkans; Milan Brglez, Samo Novak, Staša Tkalec: Stereotyping and human rights law: an (un)conventional approach of the European Court of human rights; Matevž Rašković, Boštjan Udovič: Exploring stereotypes among former Yugoslav countries: a methodology; Andrej Benedejčič: Slovenia and its relations with russia in the euro-atlantic context; Helena Kovačič, Andrej Rus: Innovations in organizations: an integrative framework Matjaž Uršič: Online news media and local stakeholders in the process of urban development - the case of plečnik stadium renovation in Ljubljana; Viktorija Car, Lidija Kos-Stanišić, Zrinka Viduka: Limitations of softpower public diplomacy; Jana Pečnikova: Volunteering and activism as forms of active citizenship; Ružica Jakešević, Siniša Tatalović: Securitization (and desecuritization) of the European refugee crisis: Croatia in the regional context 